\title{
Quantifying the Impact of Mounted Load Carrying on Equids: A Review
}

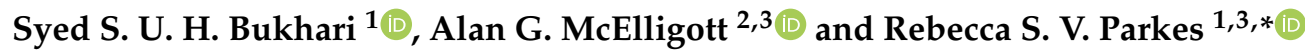 \\ 1 Department of Veterinary Clinical Sciences, Jockey Club College of Veterinary Medicine and Life Sciences, \\ City University of Hong Kong, Hong Kong, China; habukhari2-c@my.cityu.edu.hk \\ 2 Department of Infectious Diseases and Public Health, Jockey Club College of Veterinary Medicine and \\ Life Sciences, City University of Hong Kong, Hong Kong, China; alan.mcelligott@cityu.edu.hk \\ 3 Centre for Companion Animal Health, Jockey Club College of Veterinary Medicine and Life Sciences, \\ City University of Hong Kong, Hong Kong, China \\ * Correspondence: reparkes@cityu.edu.hk
}

check for updates

Citation: Bukhari, S.S.U.H.; McElligott, A.G.; Parkes, R.S.V. Quantifying the Impact of Mounted Load Carrying on Equids: A Review. Animals 2021, 11, 1333. https:// doi.org/10.3390/ani11051333

Academic Editors: Carol Hall, Anne Stevenson and Chris W. Rogers

Received: 1 April 2021

Accepted: 5 May 2021

Published: 7 May 2021

Publisher's Note: MDPI stays neutral with regard to jurisdictional claims in published maps and institutional affiliations.

Copyright: (c) 2021 by the authors. Licensee MDPI, Basel, Switzerland. This article is an open access article distributed under the terms and conditions of the Creative Commons Attribution (CC BY) license (https:// creativecommons.org/licenses/by/ $4.0 /)$.
Simple Summary: The overloading of equids has become an important issue among veterinarians, trainers, riders, and welfare advocates. Increased weight carrying may have negative effects on biomechanical, physiological, biochemical, and behavioral parameters of equids during exercise, including causing gait asymmetry or lameness. It is important to determine how to carefully quantify the load-carrying capacity of both ridden horses and working equids. There are many options to assess the effect of loading on an animal's body, but these have been inconsistently applied, making it difficult to reach a consensus, even for horses. This review summarises current knowledge of the load-carrying ability for horses and donkeys and the different parameters used to determine the effect of loading on these equids. Further research is needed to develop evidence-based guidelines for maximum loading in equids. Quantified loading limits or indicators of overloading could be used by stakeholders working with sports and pleasure horses and working equids to limit overloading and to improve the welfare of these animals.

Abstract: There are approximately 112 million working equids in developing countries, many of which are associated with brick kilns. Brick kilns and overloading are associated with welfare problems in working equids. Understanding equids' abilities and influencing factors are important for both effective performance and welfare. Traditionally, measurement of the amount of 'bone' was used, and more recently, gait symmetry has been identified as a potential marker for loading capacity. Assessment of stride parameters and gait kinematics provides insights into adaptations to loading and may help determine cut-off loads. Physiological factors such as the ability to regain normal heart rates shortly after work is an important tool for equine fitness assessment and a more accurate measure of load-carrying capacity than absolute heart rate. Oxidative stress, plasma lactate, and serum creatine kinase activity are reliable biochemical indicators of loading ability. For monitoring stress, salivary cortisol is superior to serum cortisol level for assessment of hypothalamus-pituitary-adrenal axis and is related to eye temperatures, but this has yet to be interpreted in terms of load-carrying ability in equids. Further research is needed to standardize the evidence-based load-carrying capacity of working horses and donkeys.

Keywords: blood chemistry; donkey; equid welfare; horse; limb biomechanics; loading; performance

\section{Introduction}

Horses (Equus caballus) and donkeys (Equus asinus) are ridden and used globally for pleasure, sport, and transport. Equids have always had an important role, especially in developing countries, in load-carrying [1,2], transport, draught, and agricultural production $[3,4]$ (Figure 1). There are an estimated 112 million working equids in developing countries [5]. For example, countries that have large working equid populations include 
China, Mexico, Ethiopia, Pakistan, and India, with 15.1, 12.9, 9, 5.5, and 1.5 million working equids, respectively. The importance of working equids is well known, but no research has quantified the amount that they are worth to the economies of these countries [5]. Although their power has been superseded by machinery in many developed countries, they remain as relevant as technology in some regions of the world because animal power is cheaper and easier to maintain compared to motorized modern power [6].

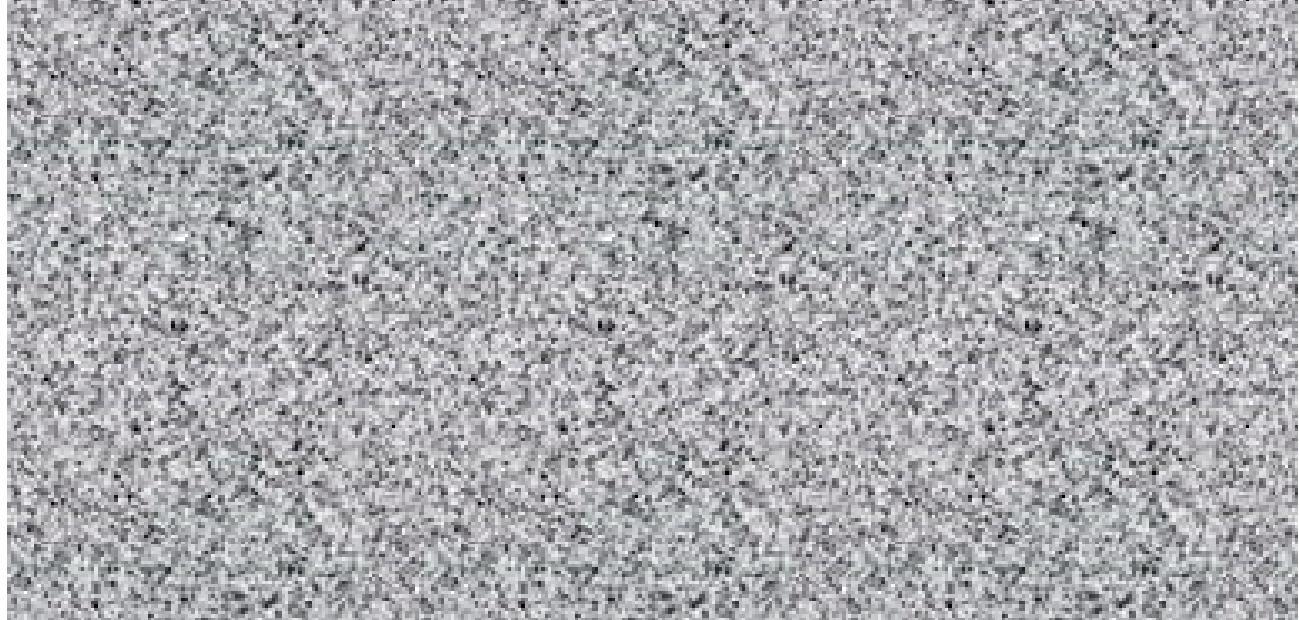

Figure 1. Working donkeys involved in the transportation of agricultural load (Lucerne and wheat straw) in central Punjab-Pakistan. Photo: Syed Saad Ul Hassan Bukhari.

Overworking and overloading have been reported as the most important issue in working horses and donkeys [7-9]. Overloading is defined as the weight with which gait rhythm is disrupted [10], leading to lameness and alteration of behavior [11]. Equines, especially donkeys, may be subject to overloading. This is a welfare concern [12] that requires improvement [1,2]. For ridden equids used for both work and pleasure, increased human bodyweight [11] is a potential welfare problem because people are getting heavier [13]. Obesity rates are increasing in human populations [14-18] as the prevalence of overweight adults increases, from 1981 to 1996, among men and women from $48 \%$ to $57 \%$ and $30 \%$ to $35 \%$, respectively [15]. The increase in a rider's weight (Figure 2) affects biomechanical, physiological, biochemical, and behavioral parameters of equids [10,11,19-22]. For working equids, carrying heavy loads is associated with increased income for their owners, leading to overloading by economic necessity [23].

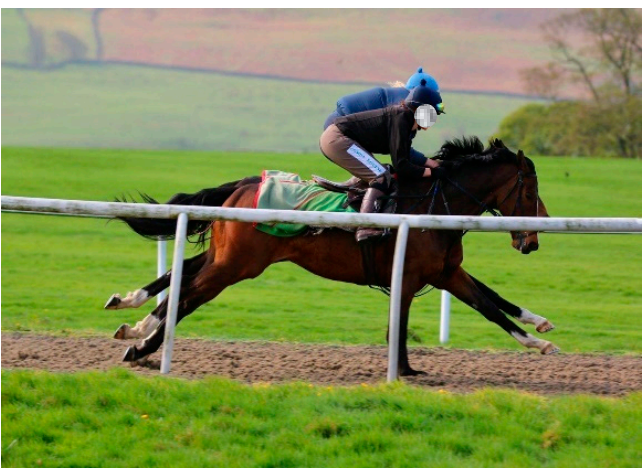

(a)

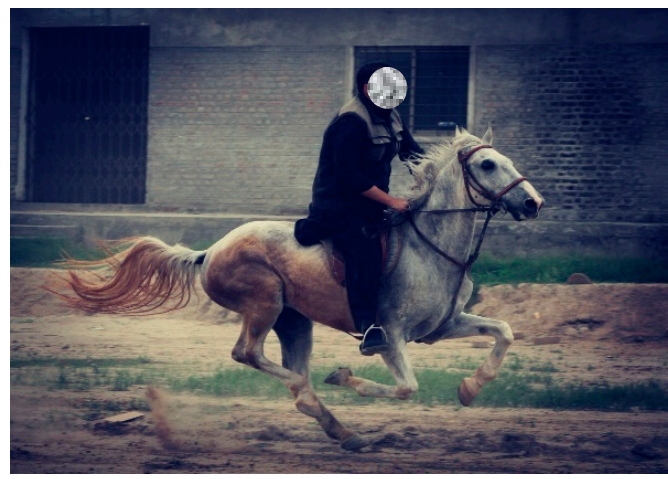

(b)

Figure 2. Horses with their riders: (a) A horse and a rider with BWR 11.96\% in the UK. Photo: Mick Atkins; (b) A horse and a rider with BWR 24.21\% in Faisalabad, Pakistan. Photo: Sabir Hussain.

The effect of a rider's bodyweight (BW) on the health, performance, and welfare of horses is frequently debated in studies of horse-rider relationships [13]. Increased 
rider weight has a negative effect on biomechanical, physiological, biochemical, and behavioral parameters of horses during exercise $[11,21,22,24]$. The weight a horse can carry is important, and it depends upon a number of physical traits, including size, age, body condition score, body conformation, duration of work, third metacarpal bone circumference, type of work, and the intensity of the work to be performed [24]. Overall this subject is poorly studied [24], and most research has been undertaken on Icelandic horses, which are traditionally subjected to a high rider:horse bodyweight ratios as compared to larger Warmblood horses and are also exposed to higher exercise intensities than ordinary riding horses [25]. One factor that should be considered is that the impacts of mounted and harnessed loads are different, as the former is more energy demanding for a loaded trotting horse [26]. This explains why a horse moves slower carrying than pulling a given weight at a specific gait [27]. However, research results are conflicting [11,25], and many different measures have been used to assess weight carrying capacity $[10,19,20,24,28]$, making direct comparisons between studies challenging.

Donkeys differ from horses in a number of biomechanical, physiological, biochemical, and behavioral respects, and they are often undervalued in the equine world [29]. For example, in comparison to horses, donkeys have closer limbs and more upright hooves and are more suited for movement over difficult terrain instead of moving at speed. Donkeys have straight backs, low withers, and slow and smooth paces, which make them ideal for load carrying [29], although donkeys have also been used for playing polo [30]. Donkeys have a steeper dorsal hoof wall angle [31], the frog is placed more caudally, and they have $25 \%$ higher mean integument depth at the level of the third phalanx as compared to horses [29]. Sick donkeys may not appear outwardly sick; instead, they may be stoic, depressed, dull, and show reduced interest towards their environment and companions [29]. Their ears are less mobile and show less response to noises. Most of the time, they lower their head below the withers in case of ill health [29]. Lameness in donkeys is difficult to assess because it is often subtle and, when laminitic, they do not show the classic 'laminitcs stance' that is seen in horses [29]. In addition to this, working donkeys are often reluctant to trot on demand, making assessing lameness harder [32]. These differences should be considered when comparing donkeys with horses. Not much research has been carried out on donkeys, and there is no accurate and science-based permissible load carrying limit for them. However, there is evidence that overloading in these animals is common and leads to significant welfare issues such as lameness and back pain [33]. To optimize equine welfare, people using equine power should understand their limitations. The efficient use of equines depends on understanding their capabilities for work, which can influence their optimum field performance. This review discusses the biomechanical, physiological, biochemical, and behavioral effects of loading in load-carrying equids.

\section{The Role of Equids in Developing Countries}

In developing countries, rural people rely on working equids in agriculture, construction, and transportation for both goods and people [5]. Equids play an important role in livelihoods in various countries [34], including Kenya [35], Nepal [12], Mexico, Ethiopia, India, Pakistan, and China [5]. In particular, a large number of working equids are owned by poor people engaged with brick production in India, being an important source of income for these landless people [36]. Brick kilns mostly rely on equids, but the sex and species of the equids vary between countries and brick kilns. In India, Pakistan, Afghanistan, and Nepal, around 380,000, 115,000, 6900, and 2200 animals work in the brick kiln industry, respectively [12].

There are a number of causes of poor working equine welfare, for example, high workload, improper shelter, food, water, handling (whipping and poor driving), harmful practices (nostril slitting), lack of supporting infrastructure (good farriers, saddlers, and healthcare), marginalisation, harsh environmental conditions, lack of inclusion in legal systems and program enforcement [5]. Overloading of equids is one of the many issues that may lead to reduced welfare, which is a global concern [37]. Brick kiln work appears to 
be associated with greater welfare problems in working equids compared to other sectors, although the severity, range, and patterns of welfare and health issues vary between countries and brick kilns within a country [12]. The welfare of working equids should be improved through collective actions of the equid-owning communities along with organizations supporting them $[34,38,39]$.

Overloading is a problem in all sectors employing working equids, and it is common for equids to collapse under an overly heavy load of bricks [12]. Overloading leads to sprains, back sores, wounds, fractures, and other irreparable injuries in working equids [12], decreasing their work output and reducing their contribution to rural livelihoods [8]. Most of the work of horses and donkeys consists of the transportation of dry and wet bricks from a brick kiln to their destination (Figure 3). In India, Pakistan, Afghanistan, and Nepal, donkeys carry 100-120 kg, 120-135 kg, 125-150 kg, and 60-80 kg (on average) of bricks on their back during a single trip, respectively [12]. For comparison, the mean live weight of Pakistani donkeys is $115 \mathrm{~kg}$ (range, 67-153 kg) [40] and the weight of indigenous Indian donkeys ranges between 110-142 kg [28]. Every day, equids carry tons of weight, which likely exceeds their natural weight carrying capacity. This is a welfare concern, and this situation becomes further undesirable due to poor management and husbandry practices leading to musculoskeletal issues [5]. Lack of knowledge and understanding about brick kilns and working equids is mainly due to insufficient research and lack of scientific data; existing data is confusing and mainly extracted from related research that cannot be directly applied to working equines [12].

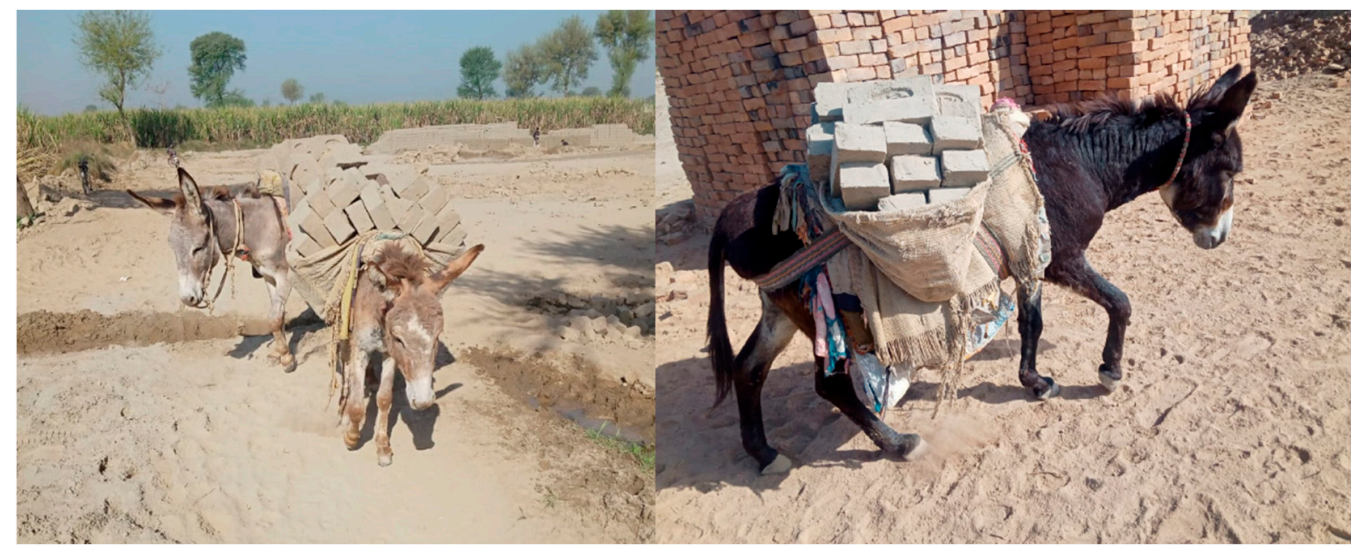

Figure 3. Brick kiln donkeys involved in the transportation of bricks in southern Punjab, Pakistan. Photo: Syed Saad Ul Hassan Bukhari.

\section{Physiological Effects of Loading}

Physiological indicators such as heart rate [21,24,28,41,42], rectal temperature [21,28,41], respiratory rate [21,28], hematocrit [21,28], cost of energy [43,44], and muscle factors [24,45] have been studied in relation to the loading capabilities of horses and donkeys. However, the number of studies is not sufficient for detailed knowledge of the effect of load on physiological parameters of equids. Compared to horses, donkeys have different resting body temperature $\left(36.5-37.7^{\circ} \mathrm{C}\right)$, heart rate $(31-53$ beats $/ \mathrm{min}$.), and respiration rate (13-31 breaths per min) ranges. Moreover, normal respiration rates change with changes in workload and environmental temperature. When compared to horses, donkeys' red blood cells and packed cell volume are normally lower, whereas mean corpuscular volume is higher in donkeys [29]. Most of the studies (on the impact of loading) are done on horses, and data from them may not be applicable to working donkeys.

Generally, heart rate increases with higher loads [41,42]. This change is often linear [21], and an increase of 54-59 beats/minutes occurs with a load of 25-30\% BW of the horse [24]. Smaller increases in the mounted weight from $12-23 \%$ of the horse's bodyweight do not result in a significant alteration in heart rate during a five-minute and twenty-second exercise test [25]. In donkeys walking at speeds of 0.42 to $0.55 \mathrm{~ms}^{-1}$ (for a maximum 
duration of $6 \mathrm{~h})$, pulse rate increases by 18.87, 21.44, and $20.38\left(\mathrm{~min}^{-1}\right)$ with increasing mounted load from $40 \%, 50 \%$, and $66 \% \mathrm{BW}$, respectively. However, the pulse rate again decreased with a load of $66 \%$ BW [28]. The ability to regain normal heart rate (resting heart rate) shortly after exercise is an important tool for equine fitness assessment [46] and may be a more accurate measure of load-carrying capacity than absolute heart rate. The type of load carried does not appear to affect heart rate, with no difference between horses carrying a rider and an equivalent weight in lead, which may reflect a minimal influence of the rider on the horse's physiological response while exercising [42], although how the rider sits can influence performance at high speeds [47].

In the process of converting stored energy into mechanical energy during exercise, horses are inefficient and lose $80 \%$ of their stored energy as heat. Moreover, they have a high metabolic capacity and relatively small surface area to dissipate heat [48]. Horses show no change in rectal temperature while increasing mounted load from $10 \% \mathrm{BW}$ to $20 \% \mathrm{BW}$ [41], but an increase in rectal temperature occurs as weight is increased from $20 \%$ to $35 \% \mathrm{BW}$ [21]. A rise of $0.3{ }^{\circ} \mathrm{C}, 0.2^{\circ} \mathrm{C}$, and $0.1^{\circ} \mathrm{C}$ superficial temperature of the back of the trunk, front of the trunk, and neck of horses occur with an increase in load to $20 \% \mathrm{BW}$ as compared to $10 \%$ [41], but it has been shown that cow's superficial temperature decreases in acute stress conditions [49]. Donkeys show an increase in rectal temperature of $1.63{ }^{\circ} \mathrm{C}$, $1.03{ }^{\circ} \mathrm{C}$, and $1.77^{\circ} \mathrm{C}$ with mounted loads of $40 \%, 50 \%$, and $66 \%$ bodyweight, working at speeds of 0.42 to $0.55 \mathrm{~ms}^{-1}$ (for a maximum duration of $6 \mathrm{~h}$ ), respectively [28].

In Icelandic horses under mounted load, respiration rate increases linearly with increasing load. An increase of 39 to 86 breaths/minute has been noted with an increase in mounted load from $20 \%$ to $35 \%$ BW [21]. Breathing frequency during exercise is limited by stride frequency at a gallop; therefore, breathing is important for post-exercise catch-up in Thoroughbred racehorses [50]. In donkeys, an increase in respiration rate by 28.86, 23.62, and 25.37 breaths / minute has been seen from pre-work to post-work with a mounted load of $40 \%, 50 \%$, and $66 \% \mathrm{BW}$, respectively. However, post-work change among the three loading groups was not significant [28]. This relationship between respiration rate and mounted load suggests that the maximum permissible load in donkeys is not $50 \% \mathrm{BW}$, and assessing the permissible load via the post-work responses may be a more valid approach to estimating load-carrying capacity in some instances.

It is well known that exercise, irrespective of its type, changes the blood parameters of horses [51,52] and donkeys [28]. In horses, mounted weight does not have any effect on hematocrit (Hct) percentage apart from being reduced $(\mathrm{Hct}=45 \%)$ after exercise with a $20 \%$ BW load as compared with a 35\% BW load. However, this change usually reverts back to normal within $30 \mathrm{~min}(\mathrm{Hct}=36)$ after exercise in Icelandic horses [21]. Donkeys differ [29], because their hematocrit (\%) increased by 3.18, 2.95, and 6.82, hemoglobin (g/dL) increased by $1.59,1.58$, and 1.72 , red blood cells (million $/ \mathrm{mm}^{3}$ ) increased by $0.83,0.8$, and 0.95 while white blood cells $\left(\times 1000 / \mathrm{mm}^{3}\right.$ ) increased by $1.99,2.02$, and 2.91 after work (for a maximum duration of $6 \mathrm{~h}$ ) with $40 \%, 50 \%$, and $66 \%$ BW ratio, respectively [28]. In horses, following exercise, adrenaline causes the release of erythrocytes from the spleen into general circulation [53]. It is likely that a similar mechanism occurs in donkeys, but differences between horses and donkeys in the context of loading have yet to be investigated.

In horses, loading increases the metabolic cost of transport. For example, the addition of $85 \mathrm{~kg}$ load, which represented 19\% of bodyweight, increased metabolic rate by $18 \%$ [44]. However, some studies in humans were unable to detect an increase in metabolic rate with vertical loading from $5 \%$ to $10 \%$ bodyweight [54]. Interestingly, the energy cost of carrying a load per unit weight of load decreases with increasing weight. In horses, the energy cost is $5.8,3.8$, and 3.7 joules per kilogram per minute, while in donkeys, the energy cost is $6.5,4.4$, and 3.0 joules per kilogram load per minute, for the weights of 13,20 , and $27 \mathrm{~kg} / 100 \mathrm{~kg}$ live weight, respectively. There is no difference between horses and donkeys [43]. Moreover, the cost of energy per unit load is the same whether weight is of additional load or the body alone [55] and an increase in speed causes increased energy consumption as compared to carrying a heavy load [56]. 


\section{Biomechanical Assessment}

Measurement of the amount of 'bone' (i.e., the circumference of the third metacarpal bone or 'cannon bone') is a traditional method to determine the weight carrying ability of a horse [57-59]. Several studies have used cannon bone measurements for the evaluation of skeletal biomechanical relationships, for example, the relation of bone strength to bone structure, stress, tension, and elasticity [57-59]. Horses with a larger cannon bone circumference and greater loin width have a greater load-carrying ability [24]. Heavy horses without a proportional increase in third metacarpal bone circumference had a higher incidence of biomechanical collapse [60], but for donkeys, this has yet to be assessed. Further studies for depth of loin muscles, the total area of loin, the usefulness of subjective evaluation of muscle soreness/tightness, and serum creatinine kinase (an enzyme representing the extent of skeletal muscle damage amid load carrying) activity are required to explain the biomechanical relationship of equids with mounted weight.

Horses adjust their gait from walk to trot or gallop at a point that minimizes energy consumption, thus managing the cost of locomotion [61]. They have a preferred speed for each particular gait type to minimize musculoskeletal stresses and enhance the metabolic economy. Loading increases musculoskeletal stresses and metabolic rate leading to a decreased preferred speed in trotting horses [44]. However, this has not been quantified in donkeys.

\subsection{Gait Stability and Symmetry}

Gait stability is defined as the sum of gait regularity (similarity on contralateral steps and similarity of consecutive strides) and gait symmetry. At a normal trot, a whole stride consists of a pair of similar dorsoventral motions, where one peak of correlation must be at each time corresponding to each half stride. Therefore, the first two peaks provide two coefficients that quantify symmetry of gait and gait regularity $[19,20,62]$. Gait symmetry is related to lameness, with animals demonstrating gait asymmetry above a certain threshold, sometimes adjusted for breed or use, considered to be lame [63-66]. Gait symmetry and load-induced lameness have also been used as markers for loading capacity $[10,19,20]$, and it has been suggested that carrying an inappropriately high weight may induce lameness in horses [11]. Trot symmetry decreases with increased weight carried in Japanese horses [19]. This effect is not seen during walking [20]. Gait symmetry is reduced, and lameness has been observed in horses of mixed breeds, with rider weights of up to $27.5 \%$ horse BW [11], but not in another using rider weights of up to $23 \%$ horse BW [25].

While trotting, gait stability decreases significantly when carrying $120 \mathrm{~kg}$ compared to $70 \mathrm{~kg}$ in Taishuh ponies [19], and in Yonaguni ponies (Japanese Landrace horses) carrying $70 \mathrm{~kg}$ compared with no load [10]. However, Taishuh ponies are generally small in size, with bodyweights between $216 \mathrm{~kg}$ and $265 \mathrm{~kg}$ [19]. Yonaguni pony bodyweight varies from $192 \mathrm{~kg}$ to $227 \mathrm{~kg}$ [10]. Again, during walking, no difference in gait stability was observed in Japanese native horses when carrying loads [20], and this may be due to low speed during a walk. Gait stability as a measure of load-carrying capacity has not been used by other authors in assessing horse and donkey gait.

\subsection{Stride Parameters}

In order to explain locomotor changes quantitatively, both angular stride variables (such as fetlock range of motion and maximum fetlock angle) and temporal stride variables (swing duration, relative stance, and stride duration) are important [67]. Assessment of stride parameters and gait kinematics provides further insight into biomechanical adaptations to loading and may help determine cut-off loads. Stance time is likely to be particularly important because stance time as a proportion of stride time gives duty factor, which is a useful proxy for peak vertical ground reaction force; therefore, limb load [68]. Stance time is the period of time during which the foot is in contact with the ground surface [69], stride time is the time elapsed between the first contact of two consecutive footsteps of the same foot [70], duty factor is the fraction of stride for which the foot remains 
on the ground [71], and ground reaction force is the force exerted by the ground on the body during contact [72]. Fetlock flexion is also directly proportional to limb load [73] and, therefore, may also be useful in assessing adaptations to load carrying. Limb load is important in this context because the peak loading capacity of the limbs is thought to limit speed in horses [74]. By increasing the load carried by the animal, the load carried by each individual limb is also increased, and if the load applied is sufficient and not limited by other factors, peak limb loading limits may be reached.

For horses moving on a treadmill, stride duration becomes longer (as stride frequency becomes $1.6 \%$ slower), carrying a load of 19\% BW [75]. An increase in stance duration has been seen in Dutch Warmblood horses under-mounted rider or dead weight compared to an unloaded situation [42]. In Icelandic horses, an increase in the bodyweight ratio (from $20 \%$ to $35 \%$ ) causes a decrease (from $2.63 \mathrm{~m}$ to $2.58 \mathrm{~m}$ ) in stride length and increase in duty factor (from $40.8 \%$ to $43.2 \%$ ) proportionally to the same extent in all four limbs [22]. Foot contact time increases by $7.7 \%$ in horses carrying loads (19\% BWR) on a level surface, but no difference has been found for an incline under the same conditions [75].

An increase in mounted load predictably leads to an increase in ground reaction force at the trot. This is greater in the front legs than the hind legs, which may be due to changes in rider position at the trot, thus changing the center of mass [76]. During shortterm exercise, the rider's bodyweight does not affect the gait biomechanics of Warmblood horses [25]. An increase in step length has been observed in Arabian horses at trot [45,75]. In Icelandic horses, a decrease in stride length (from 2.63 to $2.58 \mathrm{~m}$ ) and an increase in stride frequency (from 2.09 to 2.12 strides/s) have been seen with additional weight from $20 \%$ BWR to 35\% BW [22]. However, the differences between tölt (running walk, a gait used by Icelandic horses) and trot should be kept in mind when interpreting the differences in their comparative biomechanical studies. The trot is a two-time gait with the bodyweight of the horse usually supported on a diagonal pair of limbs at any one time, while at the tölt, the horse often has tripedal or even quadrupedal support [77], therefore reducing the maximum load on each individual limb. A tölting horse has a briefer stance duration, higher stride rate, lower stride impulses, shorter stance duration in forelimbs, higher peak vertical force in forelimbs, longer stance duration in hindlimbs, lower peak vertical force in hindlimbs, and comparatively higher head-neck position that is the cause of no weight shift towards the hindlimbs. There is also a higher forefoot flight along with lower protraction. However, variation in stride to stride timings are greater in tölt as compared to trot, but all limbs during trot typically present a spring-like mechanism [77]. Different authors have employed different measures under a variety of conditions for assessing gait changes in response to load-carrying $[10,11,19,20,22,25,75]$. This lack of consistency means that, at present, it is difficult to formulate accurate calculations for weight carrying ability in horses or donkeys based on biomechanical changes.

\section{Changes in Blood Biochemistry}

A large number of biochemical and enzymatic factors such as blood lactate, creatinine kinase, malondialdehyde, nitrates, nitrites, glutathione, retinol, tocopherol, cholecalciferol, lactate dehydrogenase, and cortisol level have been studied in relation to the loading abilities of equids [21,24,25,28,42,78]. However, the number of studies is not adequate for optimum coverage of the effect of load on biochemical parameters of equids.

Plasma lactate concentration is a reliable parameter for the measurement of the effect of load [79]. Plasma lactate level increases (from 3.6 to $7.9 \mathrm{mmol} / \mathrm{L}$ ) exponentially with the increase in the horse:rider bodyweight ratio from $20 \%$ to $35 \%$. Plasma lactate concentration returns to its normal level $(0.9 \mathrm{mmol} / \mathrm{L})$ at 24 to $48 \mathrm{~h}$ post-exercise, which is much slower compared to heart rate recovery. Aerobic metabolism of lactate is more efficient with a $20 \%$ bodyweight ratio compared to a $35 \%$ bodyweight ratio, indicating a more efficient recovery [21]. Horses mainly work aerobically until the bodyweight ratio becomes $22.7 \%$. However, individual differences exist (17-27.5\%), which may be linked to body condition score rather than body size. The size of the animal is not the decisive factor of how much an 
animal can carry [21]; overall body condition score is more important than the bodyweight ratio for performance [80]. Plasma lactate level immediately after exercise and ten minutes post-exercise was lower in horses carrying $15 \%, 20 \%$, and $25 \%$ bodyweight ratios compared to a $30 \%$ bodyweight ratio [24]. There was no difference found between mounted and lead loaded horses; however, in that particular investigation, horses carried only $12.6 \%$ and $16.3 \%$ of their bodyweight [42]. In loaded donkeys, plasma lactate concentrations were higher in all $40 \%(1.03 \mathrm{mmol} / \mathrm{L}), 50 \%(1.20 \mathrm{mmol} / \mathrm{L})$, and $66 \%(1.14 \mathrm{mmol} / \mathrm{L})$ bodyweight groups as compared to pre-exercise concentration $(0.92-0.99 \mathrm{mmol} / \mathrm{L})$, but a greater increase was seen only in 50\% bodyweight group during post-exercise tests. Plasma lactate did not increase in $40 \%$ and $66 \%$ (as in $50 \%$ BW) bodyweight groups, but this may be because of the low speed of work [28].

The rise in serum creatine kinase enzyme activity is a useful indicator of post-exercise muscle soreness and muscle damage in humans [81], as well as skeletal muscle damage in horses [82]. Serum creatine kinase activity was higher immediately post-exercise and 24 to $48 \mathrm{~h}$ post-exercise when animals carried a weight of $30 \%$ bodyweight ratio, but no change in enzyme activity was seen when horses carried a load of $15 \%$ and $20 \%$ bodyweight ratio [24]. Interestingly, activities of plasma creatine kinase, twofold above resting level $(400 \mu / \mathrm{L})$, corresponded with a negligible amount of muscle damage [83], adding other factors which may be more important for the determination of weight-bearing ability than serum creatine kinase activity.

There is evidence of oxidative stress in horses while doing endurance and intense exercise [84]. The importance of the relationship between oxidative tissue damage and physical activity has been studied in humans and animals. As metabolism increases due to physical activity, this leads to increased production of free radicals by electron transport systems and cellular antioxidant systems giving their response to these free radicals. Malondialdehyde is a naturally occurring organic compound and is an oxidative stress marker in biological systems [78,85-87]. The levels of malondialdehyde increase (from 0.78 to $1.22 \mathrm{nmol} \mathrm{mL}^{-1}$ ) after work with heavy loads in equids and provide evidence of disturbance of cellular oxidative homeostasis [78]. The damage at the cellular level is controlled and prohibited by various bio-mechanisms working through many chemicals, including tocopherol and glutathione [88], and the blood level of tocopherol decreases (from 4.8 to $3.6 \mu \mathrm{g} \mathrm{mL}^{-1}$ ) and glutathione increases (from 10.6 to $20.8 \mathrm{mg} \mathrm{dL}^{-1}$ ) after work with mounted load (equivalent to $30 \%$ of their bodyweight) in healthy horses, their levels were measure using spectrophotometric methods [78]. Muscles contain a large number of receptors for cholecalciferol (Vitamin D), which helps in calcium and phosphate metabolism. Numerous studies have demonstrated the relationship of cholecalciferol to physical performance [89], and it has been demonstrated that blood level of vitamin D decreases (from 0.1 to $0.03 \mu \mathrm{g} \mathrm{mL}^{-1}$ ) with mounted load associated work in equids, its level was measured using high-performance liquid chromatography (HPLC) [78].

\section{Behavioral Measures and Indicators of Stress}

The use of behavioral indicators for the assessment of load-carrying capacity in equines is in its infancy. An equine ethogram has been used to assess pain-associated ridden behaviors in horses [90], which may be useful when used by trained assessors [91]. More recently, a grimace scale for pain has been developed for use in donkeys [92], although this has not yet been used in the field. No ethogram for use in working donkeys has yet been developed, although overall behavior is included in several existing welfare assessment frameworks [37]. The validity of ethograms for use in working donkeys may be questionable, as some working equids exhibit apathy and reduced responsiveness, likely due to sickness or chronic poor welfare conditions [93]. The use of the ridden equine ethogram has demonstrated that heavier riders can induce behaviors associated with musculoskeletal pain (e.g., reluctance to move forward, tail lashing, and constant movement of head with ears back) and temporary lameness in horses [11]. Various breeds of horses were used, including Warmblood, Thoroughbred, Cob type, Irish Sport Horse, 
and Lusitano. If we include breed factors into weight-bearing capabilities, then this could be a limiting factor for this particular study as different breeds of horses may have different loin width and amount of 'bone' which have been shown to be important factors for weight carrying ability [24]. However, in another recent study, no changes in behavioral signs were detected with the increase in mounted weight from $12 \%$ to $23 \% \mathrm{BW}$ of the horse during low-intensity exercise ( $5 \mathrm{~min}$ and $20 \mathrm{~s}$ exercise test) [25]. Moreover, heart rate variability (vagal regulatory activity estimating high beat to beat change) was lower with heavier $(20 \% \mathrm{BW})$ riders as compared to lighter $(10 \% \mathrm{BW})$ riders [41], but heart rate variability is yet to be investigated in donkeys.

Biochemically, stress in horses can be characterized by an increased amount of exhaled nitrogen monoxide (NO) [94]. NO is a biological messenger and synthesized from amino acid (L-arginine) and, in a very short period of time, oxidizes to Nitrite $\left(\mathrm{NO}_{2}\right)$ and Nitrate $\left(\mathrm{NO}_{3}\right)$, which make it difficult to measure NO levels precisely. The concentration of NO also increases in certain pathological conditions and acts as a free radical [78,95-97]. Likewise, the concentration of nitrite and nitrate also increases $\left(\mathrm{NO}_{2} 0.78\right.$ to $0.89 \mathrm{ppm} ; \mathrm{NO}_{3} 2.01$ to $\left.4.16 \mathrm{ppm}\right)$, but a concentration of retinol (vitamin A) decreases $\left(0.50\right.$ to $\left.0.18 \mu \mathrm{g} \mathrm{mL}^{-1}\right)$ in response to work associated with load carriage up to $30 \%$ of the bodyweight in horses. These findings provide sufficient evidence that intensive work increases oxygen consumption, ultimately disturbing cellular antioxidant and pro-oxidant balance [78]. The measurement of salivary cortisol is much better than serum cortisol level for assessment of hypothalamus-pituitaryadrenal activity as it eliminates the need to care for between-subject differences in cortisol binding globulin or within-subject changes [98]. However, it is understood that cortisol is strongly linked with psychological and emotional states [99-103]. Moreover, a relationship has been found between eye temperature, salivary and plasma cortisol levels suggesting that eye temperature may also be associated with activation of hypothalamus-pituitary-adrenal activity in animals [104,105], but regarding load carrying, this should be interpreted by keeping in mind gait symmetry and behavioral data [25]. Cortisol is not a good measure of work and load-related stress because it may also be significantly affected by diet [106], genetic factors [107], environment, and characteristics associated with individuals [108]. Generally, it is considered that cortisol level increases with workload and stress, but in recent research on horses, it has been demonstrated that during short term exercise (a 5 min and 20 s exercise test), an increase in rider's weight by $15 \%$ to $25 \%$ did not result in an increase in cortisol level [25].

\section{Weight Limitations}

At this stage of scientific research, in this particular field of equine science, answering the questions related to mounted load limitations for horses and especially donkeys is difficult. This is due to the use of different methods and procedures used in different studies under different conditions [10,11,19-22,24,25,28,75]. Thus, a conclusive comparison for weight carrying ability is currently nearly impossible for equids.

It has been demonstrated that increased rider weight can have a negative effect on biomechanical, physiological, biochemical, and behavioral parameters of horses during work $[11,21,22,24]$. However, one more recent study showed that increasing mounted weight from $12 \%$ to $23 \%$ BW of the horse did not result in significant changes in heart rate, gait symmetry, behavior, and cortisol level during low-intensity work (5 min and $20 \mathrm{~s}$ exercise test) [25]. These conflicting recent results could be resolved by doing more detailed research on single horses with different riders with similar weight and exercise intensity to study the effect of riders beyond their weight.

The maximum permissible load carriage for native Japanese horses (bodyweight $339.9 \pm 37.5 \mathrm{~kg}$ ) has been suggested as less than $100 \mathrm{~kg}$, a number established after studying gait parameters, which is about $29 \%$ of an adult horse bodyweight $[19,20]$. On Yonagunai ponies (Japanese Landrace horses), it was hypothesized that a gradual increase in load on trotting ponies will lead to the point of biomechanical compromise, i.e., change in gait symmetry and regularity. They established that maximum permissible load carriage for 
trotting Japanese land race ponies is less than $70 \mathrm{~kg}$, which is $33 \%$ of its BW [10], and for Taishuh ponies (Japanese small breed horse) permissible load carriage is less than $100 \mathrm{~kg}$ (about $43 \%$ of its BW) trotting at a speed of $3.00 \mathrm{~ms}^{-1}$ [19]. However, to improve welfare, it is vital to find out loading capacity for individual breeds of horses that vary in average bodyweight [10]. Individual variations in the proportion of muscle fiber can affect metabolic responses [109], and genetics could have an important role in the weight carrying capacity of horses [21].

For donkeys, little research has been done measuring load-associated changes in physiological and biochemical parameters. It was concluded that Indian indigenous donkeys could safely carry loads up to $50 \%$ bodyweight [28]. Interestingly, lactate levels did not increase for loads of $40 \%$ and $66 \%$ compared to results for loads of $50 \%$ bodyweight [28]. Most importantly, biomechanical and behavioral measures were not considered in this study, and the results shown are based on physiological and biochemical parameters, while biomechanical and behavioral responses are yet to be investigated. Donkeys working on United Kingdom beaches are limited to carry not more than $51 \mathrm{~kg}$ [110], representing approximately $28 \%$ of their BW. However, this recommendation is based on experience rather than scientific evidence. Additionally, these donkeys are doing short rides at a slow speed [111] on a fairly level surface with a good body condition score. Working donkeys in other contexts are often working on uneven or steep terrain [12,29]. In donkeys, load density does not affect the cost of transport [43]; however, incline does affect metabolic responses and work rate [112].

\section{Conclusions}

Overloading of equids is one of the many issues that may seriously compromise their welfare. Over the last three decades, much work has been done to understand the effect of mounted load on the performance of horses, but its effect on donkeys is less studied. We know that different Japanese horse breeds can carry $29-43 \%$ of their bodyweight, but no similar research has been carried out for other horse breeds or donkeys. Loading affects a large number of biomechanical, physiological, biochemical, and behavioral features of equines, and further research is required to advance our current understanding of these factors. Quantified loading limits or indicators of overloading could then be used by NGOs, policymakers, and other stakeholders working with vulnerable communities and working equids to limit overloading and to improve the welfare of these animals.

Author Contributions: All authors were involved in the preparation of the manuscript and gave final approval of this manuscript. All authors have read and agreed to the published version of the manuscript.

Funding: This project was funded by City University of Hong Kong.

Institutional Review Board Statement: Not applicable.

Data Availability Statement: Not applicable.

Conflicts of Interest: The authors declare no conflict of interest.

\section{References}

1. Hameed, A.; Tariq, M.; Yasin, M.A. Assessment of Welfare of Working Donkeys and Mules Using Health and Behavior Parameters. J. Agric. Sci. Food Technol. 2016, 2, 69-74.

2. Hameed, A.; Saghir, A.; Ashraf, I.; Asghar, K.; Muhammad, S.A. An assessment of the Brooke International extension related activities for the welfare of equine in district Faisalabad, Punjab, Pakistan. Glob. Vet. 2014, 12, 470-473. [CrossRef]

3. Akhtar, S.; Younas, M.; Iqbal, A.; Alam, M.Z. Management profile and contribution of livestock in poverty alleviation and nutritional improvement in peri-urban areas of Faisalabad. Pak. J. Agric. Sci. 2008, 45, 381-385.

4. Fsahaye, S.; Kumar, N.; Kebede, E.; Abebe, N. Health and welfare assessment of working donkeys in and around Rama town, Tigray, Ethiopia. Ethiop. Vet. J. 2018, 22, 26-39. [CrossRef]

5. The Brooke. Available online: https://www.thebrooke.org/sites/default/files/Advocacy-and-policy/Invisible-workers-report. pdf (accessed on 16 November 2020). 
6. Starkey, P. A world-wide view of animal traction highlighting some key issues in eastern and southern Africa. In Proceedings of the First Workshop of the Animal Traction network for Eastern and Southern Africa, Lusaka, Zambia (Technical Centre for Agricultural Co-operation (CTA), Wageningen, The Netherlands), 18-23 January 1994; pp. 66-81.

7. The Brooke. Available online: https://www.thebrooke.org/sites/default/files/Ethiopia-livelihoods-2020-01.pdf (accessed on 9 October 2020).

8. FAO-Food and Agriculture Organization of United Nations. Available online: http://www.fao.org/3/i3381e/i3381e.pdf (accessed on 9 October 2020).

9. Tesfaye, M.; Bojia, E.; Feseha, G.; Ayele, G.; Alemayehu, F.; Lemessa, G.; Manhalishal, E.; Seyium, F.; Amare, B.; Dereje, N.; et al. Community-based harness development initiative for pack donkeys: A progress report, Ethiopia. In Proceedings of the 6th International Colloquium on Working Equids: Learning from others, New Delhi, India, 29 November-2 December 2010; pp. 284-291.

10. Matsuura, A.; Mano, H.; Irimajiri, M.; Hodate, K. Maximum permissible load for Yonaguni ponies (Japanese landrace horses) trotting over a short, straight course. Anim. Welf. 2016, 25, 151-156. [CrossRef]

11. Dyson, S.; Ellis, A.D.; Mackechnie-Guire, R.; Douglas, J.; Bondi, A.; Harris, P. The influence of rider:horse bodyweight ratio and rider-horse-saddle fit on equine gait and behaviour: A pilot study. Equine Vet. Educ. 2020, 32, 527-539. [CrossRef]

12. The Brooke. Available online: https://www.thebrooke.org/sites/default/files/Downloads/BrickbyBrickreport.pdf (accessed on 10 October 2020).

13. Reilly, J.J.; El-Hamdouchi, A.; Diouf, A.; Monyeki, A.; Somda, S.A. Determining the worldwide prevalence of obesity. Lancet 2018, 391, 1773-1774. [CrossRef]

14. Broussard, B.A.; Johnson, A.; Himes, J.H.; Story, M.; Fichtner, R.; Hauck, F.; Bachman-Carter, K.; Hayes, J.; Frohlich, K.; Gray, N. Prevalence of obesity in American Indians and Alaska natives. Am. J. Clin. Nutr. 1991, 53, 1535S-1542S. [CrossRef] [PubMed]

15. Tremblay, M.S.; Katzmarzyk, P.T.; Willms, J.D. Temporal trends in overweight and obesity in Canada, 1981-1996. Int. J. Obes. 2002, 26, 538-543. [CrossRef]

16. Sherin, A. Obesity: How to prevent pakistani people from getting heavier? Khyber Med. Univ. J. 2013, 5, 59-60.

17. Bonellie, S.R.; Raab, G.M. Why are babies getting heavier? Comparison of Scottish births from 1980 to 1992. BMJ 1997, $315,1205$. [CrossRef] [PubMed]

18. Taubes, G. As obesity rates rise, experts struggle to explain why. Science 1998, 280, 1367-1368. [CrossRef]

19. Matsuura, A.; Sakuma, S.; Irimajiri, M.; Hodate, K. Maximum permissible load weight of a Taishuh pony at a trot. J. Anim. Sci. 2013, 91, 3989-3996. [CrossRef]

20. Matsuura, A.; Irimajiri, M.; Matsuzaki, K.; Hiraguri, Y.; Nakanowatari, T.; Yamazaki, A.; Hodate, K. Method for estimating maximum permissible load weight for Japanese native horses using accelerometer-based gait analysis. Anim. Sci. J. 2013, 84, 75-81. [CrossRef] [PubMed]

21. Stefánsdóttir, G.J.; Gunnarsson, V.; Roepstorff, L.; Ragnarsson, S.; Jansson, A. The effect of rider weight and additional weight in Icelandic horses in tölt: Part I. Physiological responses. Animal 2017, 11, 1558-1566. [CrossRef] [PubMed]

22. Gunnarsson, V.; Stefánsdóttir, G.J.; Jansson, A.; Roepstorff, L. The effect of rider weight and additional weight in Icelandic horses in tölt: Part II. Stride parameters responses. Animal 2017, 11, 1567-1572. [CrossRef]

23. Ali, A.B.A.; Matoock, M.Y.; Fouad, M.A.; Heleski, C.R. Are mules or donkeys better adapted for Egyptian brick kiln work? (Until we can change the kilns). J. Vet. Behav. Clin. Appl. Res. 2015, 10, 158-165. [CrossRef]

24. Powell, D.M.; Bennett-Wimbush, K.; Peeples, A.; Duthie, M. Evaluation of Indicators of Weight-Carrying Ability of Light Riding Horses. J. Equine Vet. Sci. 2008, 28, 28-33. [CrossRef]

25. Christensen, J.W.; Bathellier, S.; Rhodin, M.; Palme, R.; Uldahl, M. Increased rider weight did not induce changes in behavior and physiological parameters in horses. Animals 2020, 10, 95. [CrossRef]

26. Mottini, V.; Leleu, C.; Cotrel, C. Harnessed vs. mounted Standardbreds on the track: Changes in gait and physiological variables. Equine Vet. J. 2006, 38, 468-472. [CrossRef] [PubMed]

27. Rooney, J.; Turner, L. The mechanics of horses pulling loads. Equine Vet. Sci. 1985, 5, 355-359. [CrossRef]

28. Legha, R.; Kumar, V.; Pal, Y.; Dedar, R.; Bala, P.; Ravi, S.; Talluri, T.; Tripathi, B. Physiological, Hematological and Biochemical Responses in Non-Descript Indian Donkeys Working With Different Pack Loads in Brick Kiln Simulated Conditions. Int. J. Livest. Res. 2018, 8, 59. [CrossRef]

29. Burden, F.; Thiemann, A. Donkeys are different. J. Equine Vet. Sci. 2015, 35, 376-382. [CrossRef]

30. Hu, S.; Hu, Y.; Yang, J.; Yang, M.; Wei, P.; Hou, Y.; Marshall, F.B. From pack animals to polo: Donkeys from the ninth-century Tang tomb of an elite lady in Xi'an, China. Antiquity 2020, 94, 455-472. [CrossRef]

31. Mostafa, M.B.; Abdelgalil, A.I.; Farhat, S.F.; Raw, Z.; Kubasiewicz, L.M. Morphometric measurements of the feet of working donkeys equus asinus in Egypt. J. Equine Sci. 2020, 31, 17-22. [CrossRef]

32. Regan, F.H.; Hockenhull, J.; Pritchard, J.C.; Waterman-Pearson, A.E.; Whay, H.R. Identifying behavioural differences in working donkeys in response to analgesic administration. Equine Vet. J. 2016, 48, 33-38. [CrossRef]

33. Tadesse, D.; Asefa, Z.; Alemu, A.; Endebu, B.; Kassaye, A.; Fanta, A.; Chaburte, C. Identification of causes and associated risk factors for lameness in working donkeys in and around Bishoftu. J. Anim. Sci. Vet. Med. 2019, 4, 16-23. [CrossRef]

34. The Brooke. Available online: https://www.thebrooke.org/sites/default/files/Research/Donkey-welfare-challenges.pdf (accessed on 6 October 2020). 
35. The Brooke. Available online: https://www.thebrooke.org/sites/default/files/Advocacy-and-policy/Invisible-helpers-voicesfrom-women.pdf (accessed on 11 October 2020).

36. The Brooke. Available online: https://www.thebrooke.org/sites/default/files/Research/India/India-brick-kiln-livelihoodsposter.pdf (accessed on 11 October 2020).

37. Raw, Z.; Rodrigues, J.B.; Rickards, K.; Ryding, J.; Norris, S.L.; Judge, A.; Kubasiewicz, L.M.; Watson, T.L.; Little, H.; Hart, B.; et al Equid assessment, research and scoping (EARS): The development and implementation of a new equid welfare assessment and monitoring tool. Animals 2020, 10, 297. [CrossRef] [PubMed]

38. The Brooke. Available online: https://www.thebrooke.org/sites/default/files/Sharingtheload/SLTEnglish/Part-1-English.pdf (accessed on 9 October 2020).

39. The Brooke. Available online: https://www.thebrooke.org/sites/default/files/Sharingtheload/SLTEnglish/Sharling-the-loadsynopsis.pdf (accessed on 7 October 2020).

40. Reix Nèe Broster, C.E.; Burn, C.C.; Pritchard, J.C.; Barr, A.R.S.; Whay, H.R. The range and prevalence of clinical signs and conformation associated with lameness in working draught donkeys in Pakistan. Equine Vet. J. 2014, 46, 771-777. [CrossRef] [PubMed]

41. Wilk, I.; Wnuk-Pawlak, E.; Janczarek, I.; Kaczmarek, B.; Dybczyńska, M.; Przetacznik, M. Distribution of Superficial Body Temperature in Horses Ridden by Two Riders with Varied Body Weights. Animals 2020, 10, 340. [CrossRef]

42. Van Oldruitenbroch-Oosterbaan, M.M.S.; Barneveld, A.; Schamhardt, H.C. Effects of weight and riding on workload and locomotion during treadmill exercise. Equine Vet. J. 1995, 27, 413-417. [CrossRef]

43. Pearson, R.A.; Dijkman, J.T.; Krecek, R.C.; Wright, P. Effect of density and weight of load on the energy cost of carrying loads by donkeys and ponies. Trop. Anim. Health Prod. 1998, 30, 67-78. [CrossRef]

44. Wickler, S.J.; Hoyt, D.F.; Cogger, E.A.; Hall, K.M. Effect of load on preferred speed and cost of transport. J. Appl. Physiol. 2001, 90, 1548-1551. [CrossRef]

45. Hoyt, D.F.; Molinari, M.; Wickler, S.J.; Cogger, E.A. Effect of trotting speed, load and incline on hindlimb stance-phase kinematics. Equine Vet. J. Suppl. 2002, 34, 330-336. [CrossRef]

46. Pearson, R.A.; Vall, E. Performance and management of draught animals in agriculture in sub-Saharan Africa: A review. Trop. Anim. Health Prod. 1998, 30, 309-324. [CrossRef] [PubMed]

47. Pfau, T.; Spence, A.; Starke, S.; Ferrari, M.; Wilson, A. Modern Riding Style Improves Horse Racing Times. Science 2009, 325, 289. [CrossRef] [PubMed]

48. Hodgson, D.R.; Rose, R.J.; Kelso, T.B.; McCutcheon, L.J.; Bayly, W.M.; Gollnick, P.D. Respiratory and metabolic responses in the horse during moderate and heavy exercise. Pflügers Arch. Eur. J. Physiol. 1990, 417, 73-78. [CrossRef]

49. Stewart, M.; Webster, J.R.; Verkerk, G.A.; Schaefer, A.L.; Colyn, J.J.; Stafford, K.J. Non-invasive measurement of stress in dairy cows using infrared thermography. Physiol. Behav. 2007, 92, 520-525. [CrossRef] [PubMed]

50. Butler, P.J.; Woakes, A.J.; Smale, K.; Roberts, C.A.; Hillidge, C.J.; Snow, D.H.; Marlin, D.J. Respiratory and cardiovascular adjustments during exercise of increasing intensity and during recovery in thoroughbred racehorses. J. Exp. Biol. 1993, 179, 159-180. [CrossRef]

51. Art, T.; Desmecht, D.; Amory, H.; Delogne, O.; Buchet, M.; Leroy, P.; Lekeux, P. A Field Study of Post-Exercise Values of Blood Biochemical Constituents in Jumping Horses: Relationship with Score, Individual and Event. J. Vet. Med. Ser. A 1990, 37, 231-239. [CrossRef]

52. Voss, B.; Mohr, E.; Krzywanek, H. Effects of aqua-treadmill exercise on selected blood parameters and on heart-rate variability of horses. J. Vet. Med. Ser. A Physiol. Pathol. Clin. Med. 2002, 49, 137-143. [CrossRef] [PubMed]

53. Snow, D.H.; Martin, V. Effects of exercise and adrenaline on equine erythrocyte ATP content. Res. Vet. Sci. 1990, 49, 77-81. [CrossRef]

54. Cooke, C.B.; McDonagh, M.J.N.; Nevill, A.M.; Davies, C.T.M. Effects of load on oxygen intake in trained boys and men during treadmill running. J. Appl. Physiol. 1991, 71, 1237-1244. [CrossRef] [PubMed]

55. Keren, G.; Epstein, Y.; Magazanik, A.; Sohar, E. The energy cost of walking and running with and without a backpack load. Eur. J. Appl. Physiol. Occup. Physiol. 1981, 46, 317-324. [CrossRef] [PubMed]

56. Soule, R.G.; Pandolf, K.B.; Goldman, R.F. Energy expenditure of heavy load carriage. Ergonomics 1978, 21, 373-381. [CrossRef]

57. Biewener, A.A.; Thomason, J.; Goodship, A.; Lanyon, L.E. Bone stress in the horse forelimb during locomotion at different gaits: A comparison of two experimental methods. J. Biomech. 1983, 16, 565-576. [CrossRef]

58. Evans, G.P.; Behiri, J.C.; Vaughan, L.C.; Bonfield, W. The response of equine cortical bone to loading at strain rates experienced in vivo by the galloping horse. Equine Vet. J. 1992, 24, 125-128. [CrossRef]

59. Skedros, J.G.; Dayton, M.R.; Sybrowsky, C.L.; Bloebaum, R.D.; Bachus, K.N. Are uniform regional safety factors an objective of adaptive modeling/remodeling in cortical bone? J. Exp. Biol. 2003, 206, 2431-2439. [CrossRef] [PubMed]

60. Garlinghouse, S.E.; Bray, R.E.; Cogger, E.A.; Wickler, S.J. The influence of body measurements and condition score on performance results during the 1998 Tevis Cup. In Proceedings of the 16th Equine Nutrition and Physiology Society Symposium, North Raleigh Hilton, Raleigh, NC, USA, 2-5 June 1999; pp. 398-402.

61. Taylor, C.R.; Hoyt, D.F. Gait and Energetics of Locomotion in Horses. Nature 1981, 292, 239-240.

62. Barrey, E.; Auvinet, B.; Courouce, A. Gait evaluation of race trotters using an accelerometric device. Equine Vet. J. 1995, 27, 156-160. [CrossRef] 
63. Pfau, T.; Parkes, R.S.; Burden, E.R.; Bell, N.; Fairhurst, H.; Witte, T.H. Movement asymmetry in working polo horses. Equine Vet. J. 2016, 48, 517-522. [CrossRef] [PubMed]

64. Fiske-Jackson, A.; Pfau, T.; Smith, R.K.; Witte, T.H.; Bolt, D.M.; Spicer-Jenkins, C. Identifying optimal parameters for quantification of changes in pelvic movement symmetry as a response to diagnostic analgesia in the hindlimbs of horses. Equine Vet. J. 2013, 46, 759-763. [CrossRef]

65. Pfau, T.; Sepulveda Caviedes, M.F.; Mccarthy, R.; Cheetham, L.; Forbes, B.; Rhodin, M. Comparison of visual lameness scores to gait asymmetry in racing Thoroughbreds during trot in-hand. Equine Vet. Educ. 2020, 32, 191-198. [CrossRef]

66. Keegan, K.G.; Pai, P.F.; Wilson, D.A.; Smith, B.K. Signal decomposition method of evaluating head movement to measure induced forelimb lameness in horses trotting on a treadmill. Equine Vet. J. 2001, 33, 446-451. [CrossRef] [PubMed]

67. Back, W.; den Bogert, A.J.; Van Weeren, P.R.; Bruin, G.; Barneveld, A. Quantification of the locomotion of Dutch Warmblood foals. Cells Tissues Organs 1993, 146, 141-147. [CrossRef] [PubMed]

68. Witte, T.H.; Knill, K.; Wilson, A.M. Determination of peak vertical ground reaction force from duty factor in the horse (Equus caballus). J. Exp. Biol. 2004, 207, 3639-3648. [CrossRef] [PubMed]

69. Mariani, B.; Rouhani, H.; Crevoisier, X.; Aminian, K. Quantitative estimation of foot-flat and stance phase of gait using foot-worn inertial sensors. Gait Posture 2013, 37, 229-234. [CrossRef]

70. Beauchet, O.; Annweiler, C.; Lecordroch, Y.; Allali, G.; Dubost, V.; Herrmann, F.R.; Kressig, R.W. Walking speed-related changes in stride time variability: Effects of decreased speed. J. Neuroeng. Rehabil. 2009, 6, 1-6. [CrossRef] [PubMed]

71. Fihl, P.; Moeslund, T.B. Invariant gait continuum based on the duty-factor. Signal Image Video Process. 2009, 3, 391-402. [CrossRef]

72. Van Der Tol, P.P.J.; Metz, J.H.M.; Noordhuizen-Stassen, E.N.; Back, W.; Braam, C.R.; Weijs, W.A. The vertical ground reaction force and the pressure distribution on the claws of dairy cows while walking on a flat substrate. J. Dairy Sci. 2003, 86, 2875-2883. [CrossRef]

73. McGuigan, M.P.; Wilson, A.M. The effect of gait and digital flexor muscle activation on limb compliance in the forelimb of the horse Equus caballus. J. Exp. Biol. 2003, 206, 1325-1336. [CrossRef] [PubMed]

74. Tan, H.; Wilson, A.M. Grip and limb force limits to turning performance in competition horses. Proc. Biol. Sci. 2011, 278 , $2105-2111$. [CrossRef] [PubMed]

75. Hoyt, D.F.; Wickler, S.J.; Cogger, E.A. Time of contact and step length: The effect of limb length, running speed, load carrying and incline. J. Exp. Biol. 2000, 203, 221-227. [CrossRef]

76. Schamhardt, H.C.; Merkens, H.W.; Van Osch, G. Ground reaction force analysis of horses ridden at the walk and trot. Equine Exerc. Physiol. 1991, 3, 120-127.

77. Robilliard, J.J.; Pfau, T.; Wilson, A.M. Gait characterisation and classification in horses. J. Exp. Biol. 2007, 210, 187-197. [CrossRef] [PubMed]

78. Ceylan, E.; Dede, S.; Deger, Y.; Yoruk, I. Investigation of the Effects of Carrying Heavy Load on Prooxidation/ Antioxidant Status and Vitamin D3 in Healthy Horses. Asian J. Anim. Vet. Adv. 2009, 4, 41-46. [CrossRef]

79. Persson, S.G.B. Equine Exercise Physiology; Granta Publications: Cambridge, UK, 1983; pp. 441-457.

80. Garlinghouse, S.E.; Burrill, M.J. Relationship of body condition score to completion rate during $160 \mathrm{~km}$ endurance races. Equine Vet. J. Suppl. 1999, 30, 591-595. [CrossRef] [PubMed]

81. Garcia-López, D.; De Paz, J.A.; Jiménez-Jiménez, R.; Bresciani, G.; De Souza-Teixeira, F.; Herrero, J.A.; Alvear-Ordenes, I.; González-Gallego, J. Early explosive force reduction associated with exercise-induced muscle damage. J. Physiol. Biochem. 2006, 62, 163-170. [CrossRef]

82. Lindholm, A. Pathophysiology of exercise induced diseases of the musculoskeletal system of the equine athlete. Equine Exerc. Physiol. 1987, 2, 711-727.

83. Volfinger, L.; Lassourd, V.; Michaux, J.M.; Braun, J.P.; Toutain, P.L. Kinetic evaluation of muscle damage during exercise by calculation of amount of creatine kinase released. Am. J. Physiol. Integr. Comp. Physiol. 1994, 266, R434-R441. [CrossRef]

84. Williams, C.; Kronfeld, D.; Hess, T.; Saker, K.; Waldron, J.; Crandell, K.; Harris, P. Comparison of oxidative stress and antioxidant status in endurance horses in three 80-km races. Equine Comp. Exerc. Physiol. 2005, 2, 153-157. [CrossRef]

85. Marlin, D.J.; Fenn, K.; Smith, N.; Deaton, C.D.; Roberts, C.A.; Harris, P.A.; Dunster, C.; Kelly, F.J. Changes in Circulatory Antioxidant Status in Horses during Prolonged Exercise. J. Nutr. 2002, 132, 1622-1627. [CrossRef]

86. Sen, C.K.; Packer, L. Thiol homeostasis and supplements in physical exercise. Am. J. Clin. Nutr. 2000, 72, 653S-669S. [CrossRef] [PubMed]

87. Ji, L. Antioxidants and Oxidative Stress in Exercise. Exp. Biol. Med. 2003, 222, 283-292. [CrossRef] [PubMed]

88. Sies, H. Oxidative stress: From basic research to clinical application. Am. J. Med. 1991, 91, S31-S38. [CrossRef]

89. Lips, P. Vitamin D physiology. Prog. Biophys. Mol. Biol. 2006, 92, 4-8. [CrossRef]

90. Dyson, S.; Berger, J.; Ellis, A.D.; Mullard, J. Development of an ethogram for a pain scoring system in ridden horses and its application to determine the presence of musculoskeletal pain. J. Vet. Behav. Clin. Appl. Res. 2018, 23, 47-57. [CrossRef]

91. Dyson, S.; Thomson, K.; Quiney, L.; Bondi, A.; Ellis, A.D. Can veterinarians reliably apply a whole horse ridden ethogram to differentiate nonlame and lame horses based on live horse assessment of behaviour? Equine Vet. Educ. 2019, 1-9. [CrossRef]

92. Orth, E.K.; González, F.J.N.; Pastrana, C.I.; Berger, J.M.; Le Jeune, S.S.; Davis, E.W.; McLean, A.K. Development of a donkey grimace scale to recognize pain in donkeys (Equus asinus) post castration. Animals 2020, 10, 1411. [CrossRef] 
93. Burn, C.C.; Dennison, T.L.; Whay, H.R. Relationships between behaviour and health in working horses, donkeys, and mules in developing countries. Appl. Anim. Behav. Sci. 2010, 126, 109-118. [CrossRef]

94. Mills, P.C.; Marlin, D.J.; Scott, C.M.; Smith, N.C. Nitric oxide and thermoregulation during exercise in the horse. J. Appl. Physiol. 1997, 82, 1035-1039. [CrossRef] [PubMed]

95. Bredt, D.S.; Snyder, S.H. Nitric oxide: A physiologic messenger molecule. Annu. Rev. Biochem 1994, 63, 175-195. [CrossRef]

96. Torreilles, J.; Guérin, M.C. [Does nitric oxide stress exist?]. C. R. Seances Soc. Biol. Fil. 1995, 189, 389-400. [PubMed]

97. Moncada, S. Nitric oxide: Physiology, pathophysiology and pharmacology. Pharmacol. Rev. 1991, 43, 109-142.

98. Gozansky, W.S.; Lynn, J.S.; Laudenslager, M.L.; Kohrt, W.M. Salivary cortisol determined by enzyme immunoassay is preferable to serum total cortisol for assessment of dynamic hypothalamic-pituitary-adrenal axis activity. Clin. Endocrinol. 2005, 63, 336-341. [CrossRef]

99. Takai, N.; Yamaguchi, M.; Aragaki, T.; Eto, K.; Uchihashi, K.; Nishikawa, Y. Effect of psychological stress on the salivary cortisol and amylase levels in healthy young adults. Arch. Oral Biol. 2004, 49, 963-968. [CrossRef] [PubMed]

100. Khalfa, S.; BELLA, S.D.; Roy, M.; Peretz, I.; Lupien, S.J. Effects of relaxing music on salivary cortisol level after psychological stress. Ann. N. Y. Acad. Sci. 2003, 999, 374-376. [CrossRef] [PubMed]

101. Kirschbaum, C.; Wüst, S.; Hellhammer, D. Consistent sex differences in cortisol responses to psychological stress. Psychosom. Med. 1992, 54, 648-657. [CrossRef]

102. Buchanan, T.W.; Lovallo, W.R. Enhanced memory for emotional material following stress-level cortisol treatment in humans. Psychoneuroendocrinology 2001, 26, 307-317. [CrossRef]

103. Lovallo, W.R.; Farag, N.H.; Vincent, A.S.; Thomas, T.L.; Wilson, M.F. Cortisol responses to mental stress, exercise, and meals following caffeine intake in men and women. Pharmacol. Biochem. Behav. 2006, 83, 441-447. [CrossRef] [PubMed]

104. Stewart, M.; Webster, J.R.; Schaefer, A.L.; Cook, N.J.; Scott, S.L. Infrared thermography as a non-invasive tool to study animal welfare. Anim. Welf. 2005, 14, 319-325.

105. Valera, M.; Bartolomé, E.; Sánchez, M.J.; Molina, A.; Cook, N.; Schaefer, A. Changes in Eye Temperature and Stress Assessment in Horses During Show Jumping Competitions. J. Equine Vet. Sci. 2012, 32, 827-830. [CrossRef]

106. Stachowicz, M.; Lebiedzińska, A. The effect of diet components on the level of cortisol. Eur. Food Res. Technol. 2016, 242, 2001-2009. [CrossRef]

107. Meikle, A.W.; Stringham, J.D.; Woodward, M.G.; Bishop, D.T. Heritability of variation of plasma cortisol levels. Metabolism 1988, 37, 514-517. [CrossRef]

108. Yamanashi, Y.; Teramoto, M.; Morimura, N.; Hirata, S.; Inoue-Murayama, M.; Idani, G. Effects of relocation and individual and environmental factors on the long-term stress levels in captive chimpanzees (Pan troglodytes): Monitoring hair cortisol and behaviors. PLoS ONE 2016, 11, e0160029. [CrossRef]

109. Dobec, R.L.; Borger, M.L.; Neal, S.M. Correlation of real-time ultrasonic measures of fat and longissimus muscle area in Standardbred horses with lifetime racing record and lifetime winnings. J. Anim. Sci. 1994, 72, 44.

110. The Donkey Sanctuary, UK. Available online: https://www.thedonkeysanctuary.org.uk/what-we-do/knowledge-and-advice/ working-donkeys (accessed on 8 October 2020).

111. Vet Times, UK. Available online: https://www.vettimes.co.uk/app/uploads/wp-post-to-pdf-enhanced-cache/1/weightlimitations-in-horse-riding-how-big-is-too-big (accessed on 9 October 2020).

112. Mueller, P.J.; Jones, M.T.; Rawson, R.E.; Van Soest, P.J.; Hintz, H.F. Effect of increasing work rate on metabolic responses of the donkey (Equus asinus). J. Appl. Physiol. 1994, 77, 1431-1438. [CrossRef] [PubMed] 